\begin{tabular}{|c|c|c|}
\hline Beitr. Ent. & Keltern & ISSN 0005-805X \\
\hline $\mathbf{5 9}(2009) 1$ & S. $175-189$ & 15.07 .2009 \\
\hline
\end{tabular}

\title{
Exomala (Neoblitopertha) campestris (LATREILLE, 1804) and Exomala (Neoblitopertha) succincta (CASTELNAU, 1840): two distinct European species
}

\section{(Coleoptera, Scarabaeidae, Rutelinae, Anomalini)}

With 36 figures

\section{Eckehard Rössner, Carsten Zorn and Tristão Branco}

\begin{abstract}
Zusammenfassung
Es wird gezeigt, dass entsprechend dem Code Melolontha campestris Latreille, 1804, obwohl ein jüngeres primäres Homonym von Melolontha campestris Herbst, 1783, als gültiger Name für die Art Exomala (Neoblitopertha) campestris verwendet werden muss. Exomala (Neoblitopertha) succincta (CASTELNAU, 1840), welche bislang als Synonym von Exomala (Neoblitopertha) campestris LatreILle, 1804 betrachtet wurde, ist eine valide Art. Diagnostische Merkmale, die die Separation von succincta und campestris ermöglichen, sowie ein Bestimmungschlüssel für die Arten der Untergattung Neoblitopertha BARAUD, 1991, werden präsentiert.
\end{abstract}

\section{Summary}

Evidence is presented showing that, according to the Code, Melolontha campestris LATREILLE, 1804, albeit a junior primary homonym of Melolontha campestris Herbst, 1783 must to be used as the valid name for the species currently known as Exomala (Neoblitopertha) campestris. Exomala (Neoblitopertha) succincta (CASTELnau, 1840), currently considered synonym of Exomala (Neoblitopertha) campestris (LatreILle, 1804), is rehabilitated as a good species. Diagnostic features enabling the separation of succincta from campestris are provided, as well as a key to the species of Neoblitopertha BARAUD, 1991.

\section{Keywords}

Taxonomy, nomenclature, new synonymy, key to species, Coleoptera, Scarabaeidae, Anomalini, Exomala (Neoblitopertha), Palaearctic region.

\section{Introduction}

LATreille (1804) described, from southern France, Melolontha campestris, currently Exomala (Neoblitopertha) campestris. A few decades later Castelnau (1840) described two species of Anisoplia: arenaria from southern France, and succincta from Austria and Italy. Both names are currently considered synonyms of E. campestris. Subsequent authors recognized a great variability of the latter species, particularly the colour pattern of the elytra, and named several varieties (Mulsant 1842, Báguena 1955). Petrovitz (1968) defined a Blitopertha campestris-group, comprising Bl. campestris, Bl. leonii (Luigioni, 1932), Bl. adriatica Petrovitz, 1968, and Bl. bileki Petrovitz, 1968, he provided an identification key, and illustrated the aedeagi of these 
species. In his revision of the genus Blitopertha Reitter, 1903, Baraud (1991) elevated Exomala ReItTER, 1903 to the rank of genus and created the subgenus Neoblitopertha for the species of the Bl. campestris-group. BARAUD's 1991 taxonomic arrangement is currently upheld (ZoRN, 2006). Puzzlingly, BARAUD (1991) did not notice the significant differences between the aedeagus figures of Bl. campestris in Petrovitz (1968: 484, fig. 14c) and his own drawings (Baraud, 1991: 59, fig. 8a-8c, and BARAUD 1992: 740, fig. 857 [it should be noted that the legends of figures 857 and 858 are transposed]). It was this discrepancy that led one of us (E.R.) to re-examine this taxon and to conclude that Exomala campestris auctorum actually includes two very similar but distinctly different species.

\section{Material and Methods}

The Coleoptera collection of LATREILle was split at an early date, whereas the Lamellicornia collection of Castelnau was deposited via René Oberthür at the Muséum National d'Histoire Naturelle, Paris (Horn et al., 1990). However, no type material of the species-group names in the subgenus Neoblitopertha could be traced at a first search in the MNHN collections. This is unproblematic since the two recognized species can be differenciated both morphologically and geographically, and all published names can be assigned to either of the species with certainty by their original descriptions. Therefore, according to Article 75.3 of the Code, even if the types were proven lost we would refrain from designating neotypes.

The examined material is housed in the following collections:

$\begin{array}{ll}\text { MNHN } & \text { Muséum National d'Histoire Naturelle, Paris } \\ \text { NSMW } & \text { Naturwissenschaftliche Sammlung des Museum Wiesbaden } \\ \text { SMNS } & \text { Staatliches Museum für Naturkunde Stuttgart } \\ \text { SMTD } & \text { Senckenberg Museum für Tierkunde Dresden } \\ \text { MNHB } & \text { Zoologisches Museum der Humboldt-Universität zu Berlin } \\ \text { ZSM } & \text { Zoologische Staatssammlung München } \\ \text { CAW } & \text { coll. A. WEIGEL, Wernburg } \\ \text { CCZ } & \text { coll. C. ZoRN, Gnoien } \\ \text { CER } & \text { coll. E. RössNer, Schwerin } \\ \text { CJS } & \text { coll. J. SCHULZE, Berlin } \\ \text { CHK } & \text { coll. H. KALZ, Schlabendorf } \\ \text { CTB } & \text { coll. T. BRANCO, Porto }\end{array}$

The body length was measured from the apex of the clypeus to the apex of the elytra. Descriptive statistics and the statistical analysis (t-test) were performed with SPSS 14.0. The significance level was set at $99 \%(\mathrm{p}<0.01)$.

\section{Nomenclature}

As already pointed out by ÁDÁm (2003) and Zorn (2006), the name Melolontha campestris LATREILLE, 1804, currently in prevailing usage as Exomala (Neoblitopertha) campestris, is a junior primary homonym of Melolontha campestris Herbst, 1783. 
According to Article 23.9.1 of the Code (ICZN, 1999), prevailing usage must be maintained when the following conditions are both met:

23.9.1.1. the senior synonym or homonym has not been used as a valid name after 1899, and

23.9.1.2. the junior synonym or homonym has been used for a particular taxon, as its presumed valid name, in at least 25 works, published by at least 10 authors in the immediately preceding 50 years and encompassing a span of not less than 10 years.

Herbst (1783) noting many differences amongst specimens from Berlin that he had identified as "Melolontha horticola. FABR. sp. 41" (i.e., Melolontha horticola: FABricius, 1781 = Scarabaeus horticola Linnaeus, 1758, currently Phyllopertha horticola) split them into three species, Melolontha horticola and the two new species Melolontha segetum and Melolontha campestris.

Fabricius (1787) described as Melolontha fruticola the species that he believed Herbst (1783) had described on the male as Melolontha segetum, and as Melolontha campestris on the female. Melolontha fruticola FABricius, 1787 was then adopted as the valid name by subsequent authors, e.g., Olivier (1789), Gmelin (1790), Schönherr (1817), Castelnau (1840), Erichson (1847).

In his catalogue of Coleoptera, Harold (1869) recorded Melolontha segetum Herbst, 1783 (currently Chaetopteroplia segetum) as the valid name, and that was adopted as the valid name by subsequent authors, e.g., Mulsant \& Rey (1871), Reitter (1903), Bedel (1911), Ohaus (1918).

In summary, two names have been used as the valid name for the species currently known as Chaetopteroplia segetum (Herbst, 1783), Melolontha fruticola Fabricius, 1787 in the period between Fabricius's 1787 and Harold's 1869 publications, and Melolontha segetum Herbst, 1783 thereafter. Melolontha campestris Herbst, 1783 has hardly ever been used as a valid name, certainly not after 1899. Therefore, the first condition of Article 23.9.1 is met.

The list below includes in chronological order 28 works, by 22 (first) authors, encompassing a period of 49 years, where the name Melolontha campestris LATreILle, 1804 was used as the presumed valid name, fulfilling the second condition of Article 23.9.1.

1. Miкšıč (1959) [p. 120: Phyllopertha campestris (LATr.)],

2. Paulian (1959) [Phyllopertha campestris (Latr.)],

3. BÁGUENA (1967) [p. 434: Blitopertha campestris (LATR.)],

4. Petrovitz (1968) [p. 483: Blitopertha campestris (LATr.)],

5. Machatschke (1969) [p. 347: Blitopertha campestris (LATr.)],

6. Petrovitz (1969a) [p. 866: Blitopertha campestris (LATr.)],

7. Petrovitz (1969b) [p. 104: Blitopertha campestris (Latr.)],

8. Allenspach (1970) [p. 124: Phyllopertha campestris (Latr.)],

9. Mikšič (1970) [p. 42: B. (B.) campestris (LATR.)],

10. Baraud (1977) [p. 291: Blitopertha campestris (LATr.)],

11. Paulian \& Baraud (1982) [p. 363: Blitopertha campestris (Latr.)],

12. Benitez-Donoso, A. \& Garcia-Parrón, M. J. (1984) [p. 100: Blitopertha campestris (LATR.)],

13. Galante (1984) [p. 6: Blitopertha campestris (LATr.)], 
14. LuCHT (1987) [p. 238: Blitopertha campestris (LATR.)],

15. BARAUd (1991) [p. 50: Exomala (Neoblitopertha) campestris (LATR.)],

16. Косн (1991) [p. 375: Blitopertha campestris (LATR.)],

17. Baraud (1992) [p. 739: Exomala (Neoblitopertha) campestris (LATR.)],

18. Robert (1992) [p. 175: Blitopertha campestris (LATr.)],

19. Piattella \& Sabatinelli (1994) [p. 156: Exomala campestris (Latr.)],

20. Carpaneto \& Piattella (1995) [p. 15: Exomala campestris (Latr.)],

21. Krell (1995) [p. 75: Blitopertha campestris (LATr.)],

22. Klausnitzer \& Krell (1996) [p. 71: Blitopertha campestris (LATr.)],

23. Bahillo \& López-Colón (1998) [p. 169: Exomala (Neoblitopertha) campestris (LATr.)],

24. LePLAT (1998) [p. 60: Blitopertha campestris hispanica],

25. Micó \& Galante (2002) [p. 55: Exomala (Neoblitopertha) campestris (LATR.)],

26. Pesarini (2004) [p. 92: Exomala campestris (LATr.)],

27. Zorn (2006) [p. 266: Exomala (Neoblitopertha) campestris (LATr.)],

28. JaMESON et al. (2007) [p. 432: Exomala campestris (LATr.)].

Since both conditions of Article 23.9.1 are met, Melolontha campestris LATreILle, 1804 ought to be given precedence (as a nomen protectum) over Melolontha campestris Herbst, 1783 (a nomen oblitum), and must be used as the valid name.

\section{Taxonomy}

\section{Exomala (Neoblitopertha) campestris (LATREILLE, 1804)}

Melolontha campestris Latreille, 1804: 195 (type locality: „midi de la France“). Anisoplia arenaria Castelnau, 1840: 151 (type locality: „France méridionale“).

Phyllopertha campestris var. occidentalis Mulsant, 1842: 497 (type locality: Bordeaux and Mont-deMarsan).

Phyllopertha campestris var. circumcincta Mulsant, 1842: 497 (type locality: Bordeaux and Mont-deMarsan).

Phyllopertha campestris var. sabulosa Mulsant, 1842: 497 (type locality: Bordeaux and Mont-de-Marsan). Blitopertha campestris var. hispanica BáGUENA, 1955: 293 (type locality: Spain); LEPLAT, 1958: 60 [Blitopertha campestris hispanica].

Blitopertha campestris var. mulsanti BáGuena, 1955: 293 (type locality: Bordeaux and Mont-de-Marsan).

Examined material:

France: „Gall. mer., occ. ...[partly illegible] | 24645“ (1 o $o^{\star}$, historical collection, MNHB). - „24645“ (2 o ,

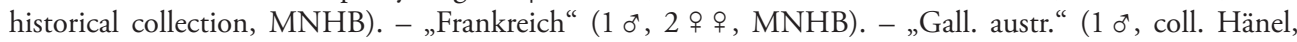
SMTD). - „Gironde: Cap Ferret, dune océan, cote 99, fleurs, 15.VI.[19]66“ (1 \&, CTB). - „Gironde: La

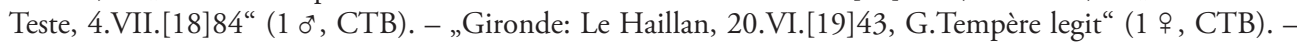
„Gironde: Le Pilat, VI.[19]47, G.Tempère legit“ (1 o , CTB). - „Gironde: Le Porge, 11.VI.[19]61, J. Aubry legit“ (2 $\left.\sigma^{\star} \sigma^{\star}, \mathrm{CTB}\right)$. - „Gironde: St. S. de Cadourne, à Barclès en fouettant, VI.[19]24“ (2 o o , CTB). - „Gironde: Soulac-sur-Mer, H.Gouin legit“ (1 ․ CTB). - „Gironde: Villeneuve d'Ornon, 2.VII.1926, G.Tempère legit“ (1 ㅇ, CTB). - „Haute-Garonne, 1924, Duffort legit (ex col. G.Tempère)“ (1 \&, CTB). - „Landes, J. Feytaud legit“ (2 우, CTB). - „Landes: env. de Mont de Marsan, 1955, J. Feytaud legit“ 
(2 $\sigma^{\star} \sigma^{\star}, 1$ ㅇ, CTB). - „Cauterets, Hautes Pyrenées | Coll. Piesbergen“ (1 o, 1 ㅇ, SMNS). - „Süd Europa | Coll. Jäger" (1 $\sigma^{\star}, 3$ 우 + , SMNS).

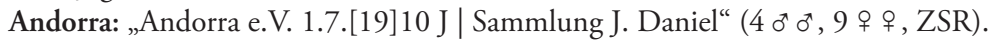
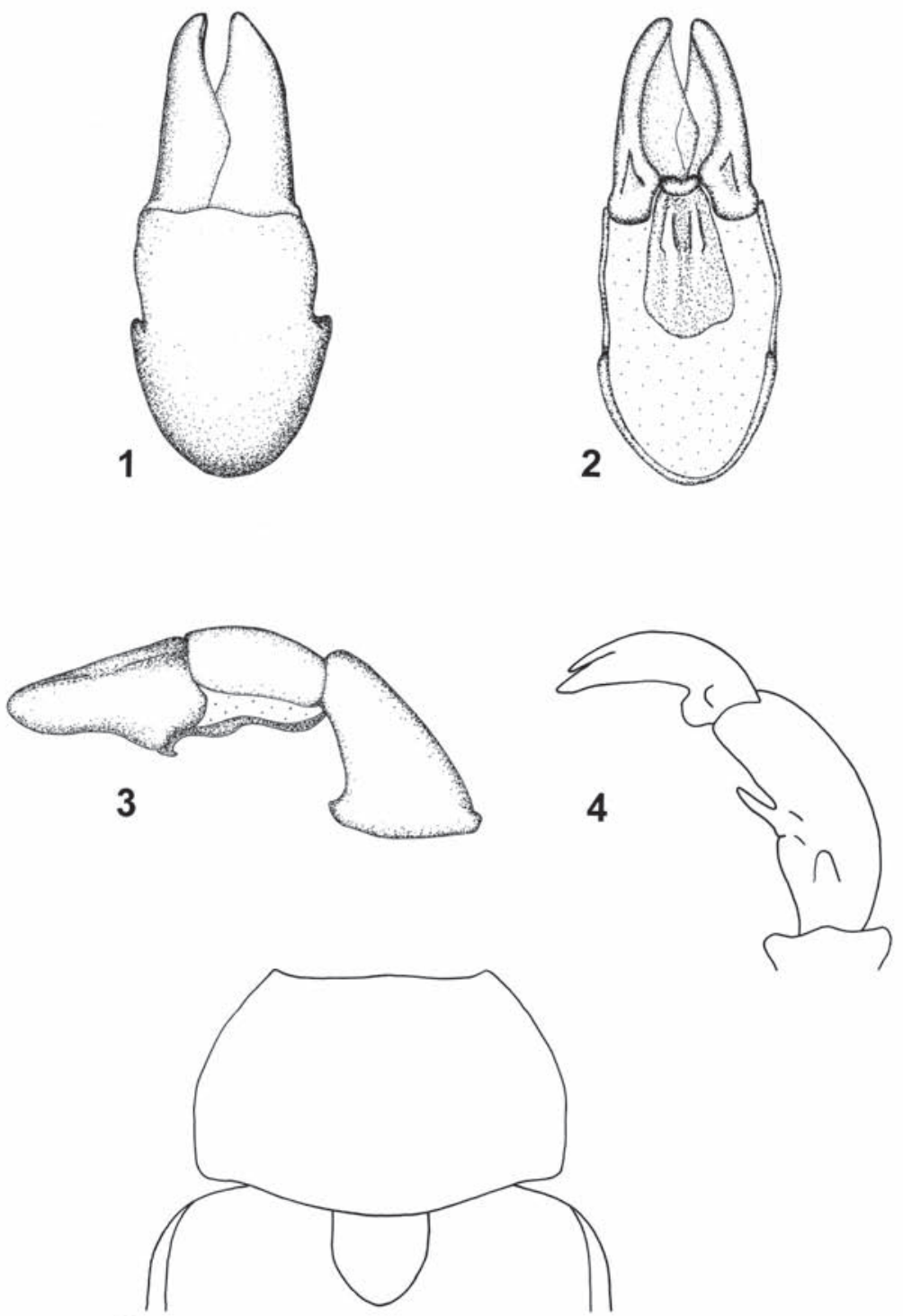

5

Figs 1-5: Exomala campestris, France, Gironde, La Teste, ơ. - 1: Aedeagus, dorsal. - 2: Aedeagus, ventral. - 3: Aedeagus, lateral. - 4: Last joint and inner claw (outer claw not shown) of right fore tarsus. - 5: Pronotum and scutellum.

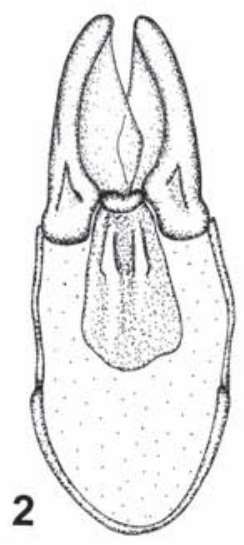


Spain: „Spanien, Prov. Lerida: Sepeira (12 km nw Tremp), 1200 m, 22.VI.1992, leg. H. Kalz“ (3 9 ㅇ, CHK). - dto., nur „leg. A. Schröder“ (1, , CER). - „Spanien, Prov. Teruel: Mas de las Matas (13 km

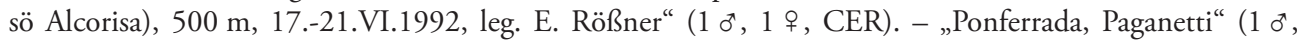
SMTD). - „Hispania“ ( 1 ๆ , coll. Felsche, SMTD).

\section{Description:}

Head, pronotum and scutellum black, shining, often with weak metallic lustre. Elytra yellowish brown, moderately shining; dark marks usually weakly developed: narrowly darkened along the periphery, umbone with a dark mark, the dark transversal band sometimes indicated.

Clypeus broadly rectangular; sides parallel; fore edge reflexed and weakly convex; anterior angles rounded; punctation transversely rugose.

Forehead and vertex with erect, light-coloured pilosity; with very dense, rugose punctation. Antennal club elongate; outer face of last antennomere weakly convex.

Pronotum (fig. 5) evenly rounded at the sides; base convex, completely margined, margin extending to the postero-lateral angles though here sometimes very thin; punctation transversely dense to rugose.

Scutellum (fig. 5) most often elongate, sometimes semicircular; densely punctate, setose.

Elytra (figs 11-16) broadest approximately in the middle; odd intervals feebly convex and weakly setose; all intervals with more or less distinct transverse, rugose punctation.

Pygidium densely transversely rugose; with moderately dense, long light-coloured pilosity.

Ventral face and femora with rather long light-coloured setae.

Inner claw of fore tarsi in males (fig. 4) relatively short, less than half as long as last tarsal joint.

\section{Exomala (Neoblitopertha) succincta (CASTELNAU, 1840), stat. rest.}

Anisoplia succincta Castelnau, 1840: 151 (type locality: Austria and Italy)

Phyllopertha campestris var. abbreviata Mulsant, 1842: 496 (type locality: Lyon), syn. nov.

Phyllopertha campestris var. cruciata Mulsant, 1842: 496 (type locality: Lyon), syn. nov.

Phyllopertha campestris var. maculata Mulsant, 1842: 496 (type locality: Lyon), syn. nov.

Phyllopertha campestris var. pauperata Mulsant, 1842: 496 (type locality: Lyon), syn. nov.

Examined material:

France: „Savoie, [illegible:] Voison“ (1 9 , MHNG). - „Frankreich“ (1 $\sigma^{\star}$, MNHB). - „Lyon“ (3 $\sigma^{\star} \sigma^{\star}$, MNHB). - „Basses Alpes, St. Andire, Juni 1966“ (3 $0^{\star} 0^{\star}, 6$ ㅜ, CJS). - „Gall. mer.“ (3 $0^{\star} o^{\star}, 1$ ㅇ, coll. Fehse, SMTD).

Italy: „Tirol mer. | 24645“ (3 ๙ $^{\star}$, historical collection, MNHB). - „Südtirol, VI.1931, leg. Schadewald“ (2 Ex., CAW). - „Tirol | 24645“ (2 o o 1 , 1 \%, historical collection, MNHB). - „Tyrol. Stentz. | 24645“ ( $1 \sigma^{\star}$, historical collection, MNHB). - „24645“ (5 $\sigma^{\star} \sigma^{\star}, 4$ 우 , historical collection, MNHB). - „Trient, Schmidt" (1 $9, \mathrm{MNHB})$. - „Trient $|89946|$ Coll. Thieme“ (1 o , historical collection, MNHB). - „Verona“ (3 ơ $^{\star}, 1$ ㅇ, MNHB). - „Toscana, [illegible:] Sinca| 69“ (1 $\left.0^{\star}, \mathrm{MNHB}\right) .-$ „Bozen“ (3 우 ․, MNHB). „Bozen | Kollektion Dr. Fuchs“ (3 o $^{\star}$, NSMW). - „Atzwang [Südtirol, zu Renon] 7.1910, g. W. Maus“ (1 ㅇ, NSMW).- „Emilia, Fiumalbo, VI.[18]94, A. Fiori | 110616“ (3 우, MNHB). - „Emilia, Reno,

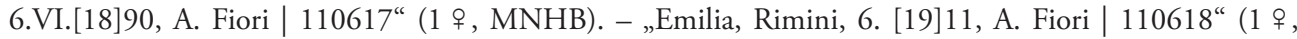
MNHB). - „Piemonte, [illegible:] Garearel, VI.[18]90, A. Fiori | 110619“ (1 + , MNHB). - „Trient, [leg.] Kirsch“ (2 ơ ơ SMTD). - „Tirol, [leg.] Märkel“ (3 ơ ơ 3 우 ㅇ, SMTD). - „Bozen, VI.1903 [leg.] Dr. Noesske“ (2 $0^{\star} 0^{\star}, 2$ 우 ㅇ, SMTD). - „Italia, [leg.] Märkel“ (2 o $^{\star} o^{\star}$, SMTD). - „Tirolis mer. | alte Sammlung“ (1 9, ZSM). - „Bozen | Sammlung Cl. Müller“ (2 $\sigma^{\star} \sigma^{\star}$, ZSM). - „Bozen 4.6.[18]84 J | Sammlung J. Daniel“

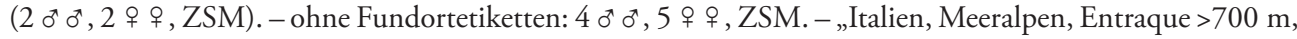
29.-31.V.1992, leg. Zorn“" (2 o o o $\left.^{\star}, \mathrm{CCZ}\right)$. 
Switzerland: „Helvet. | 24645“ (1 ð0, historical collection, MNHB). - „Helvetia | alte Sammlung“ (1 ZSM).

[We have also seen the following specimens that we believe were wrongly labelled: France: „Bordeaux | ex museo W. Weber“ (1 $\varnothing^{\star}$, MNHB). - Spain: „Spanien, Malaga“ (1 9 , MNHB). - Germany: „Germania,

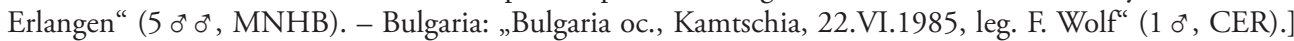

- Russia: „Ross. m. | Sammlung Cl. Müller“ (1 , ZSM).]
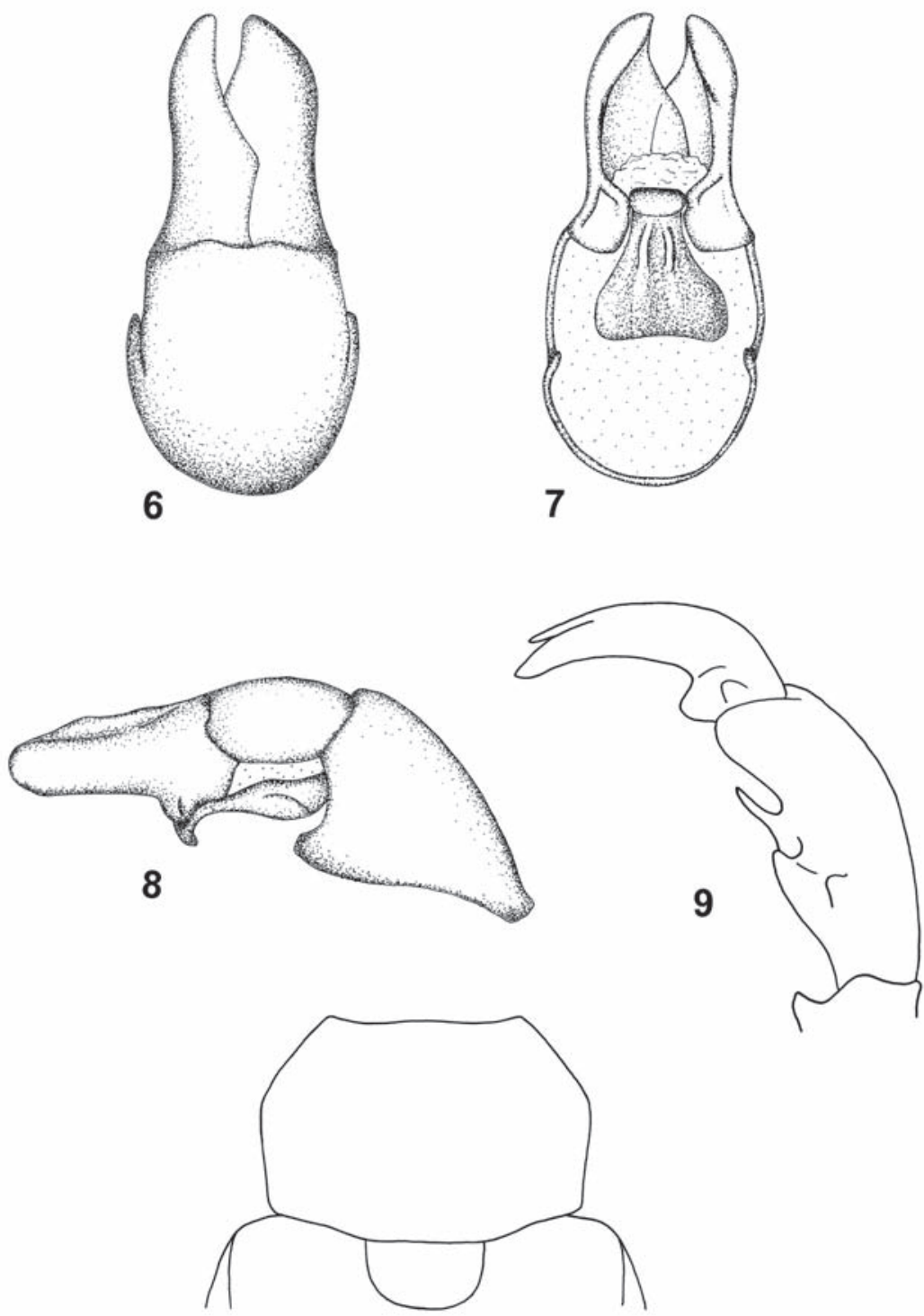

10

Figs 6-10: Exomala succincta, France, Basses Alpes, St. Andire, ơ. - 6: Aedeagus, dorsal. 7: Aedeagus, ventral. - 8: Aedeagus, lateral. - 9: Last joint and inner claw (outer claw not shown) of right fore tarsus. - 10: Pronotum and scutellum. 


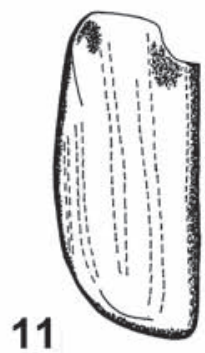

14

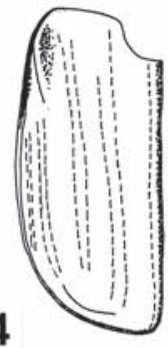

17

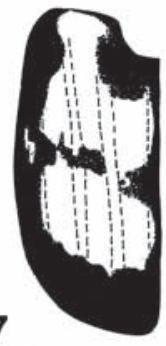

20

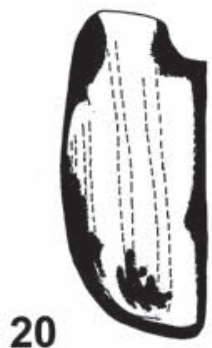

12

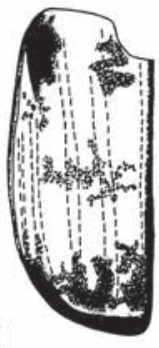

15

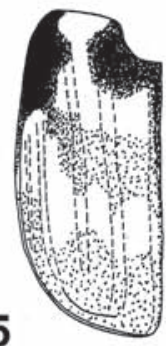

18

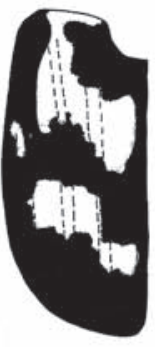

21
13

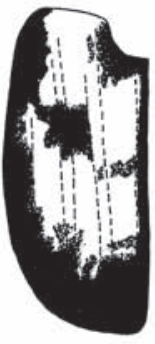

16

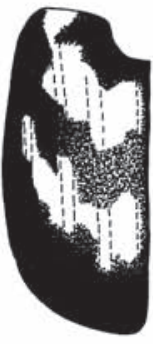

19

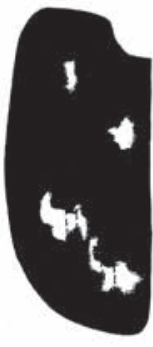

22

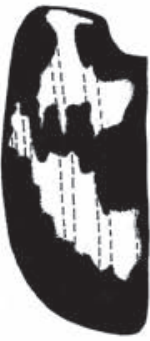

Figs 11-22: Colour pattern of left elytron. - 11-16: Exomala campestris - 17-22: Exomala succincta - 11-13, 17-19: o $^{\top} o^{\top} .-14-16,20-22$ : 우 ㅇ. . - 11, 14, 17, 20: Specimens with reduced dark marks. $-12,15,18,21$ : Specimens with moderately developed dark marks. $-13,16,19,22$ : Specimens with well developed dark marks. - 11: Gallia mer. - 12: France. - 13: Gironde: La Teste. - 14: France. - 15: France. - 16: Gironde: Soulac-sur-Mer. - 17: Tirol. - 18: Tirol mer. - 19: Tirol - 20: Emilia, Reno. - 21: Piemonte: Garearel. - 22: Bolzano. 

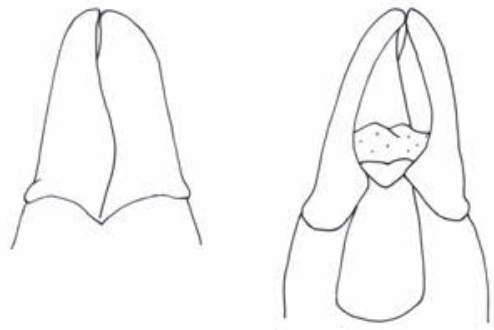

24

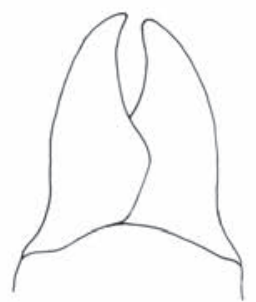

27

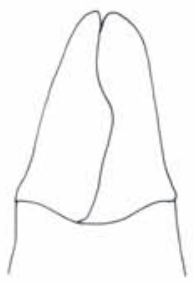

31

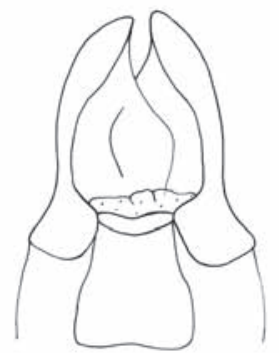

28

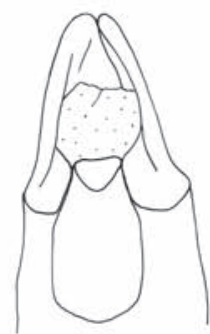

32

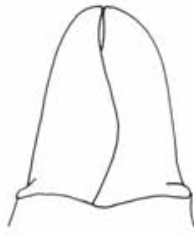

25

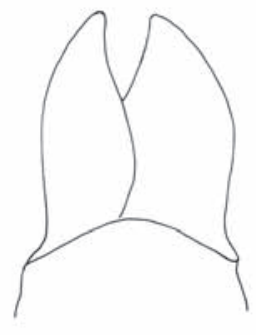

29

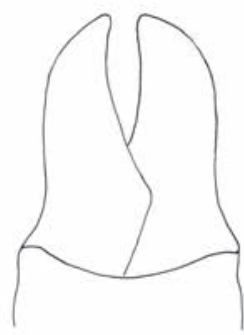

33

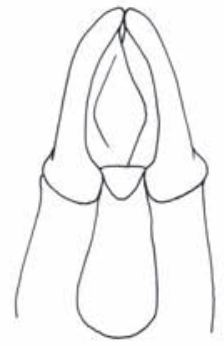

26

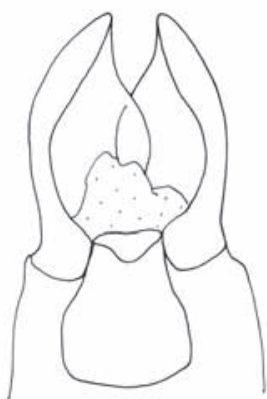

30

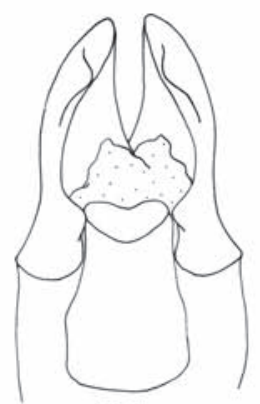

34

Figs 23-34: Male genitalia. - 23, 25, 27, 29, 31, 33: parameres in dorsal view. - 24, 26, 28, 30 , 32, 34: parameres in ventral view and ventral plate. - 23-26: Exomala campestris. - 23, 24: [Spain] Ponferrada (SMTD). - 25, 26: [France] Cauterets, Hautes Pyrenées (SMNS). - 27-30: Exomala succincta. - 27, 28: [Italia] Tirol (ZMHUB). - 29, 30: [Italia] Bozen (SMTD). - 31, 32: Exomala adriatica [Albania] Valona (SMTD). - 33, 34: Exomala bileki [Turkey] Buglan Gecidi (CER). 


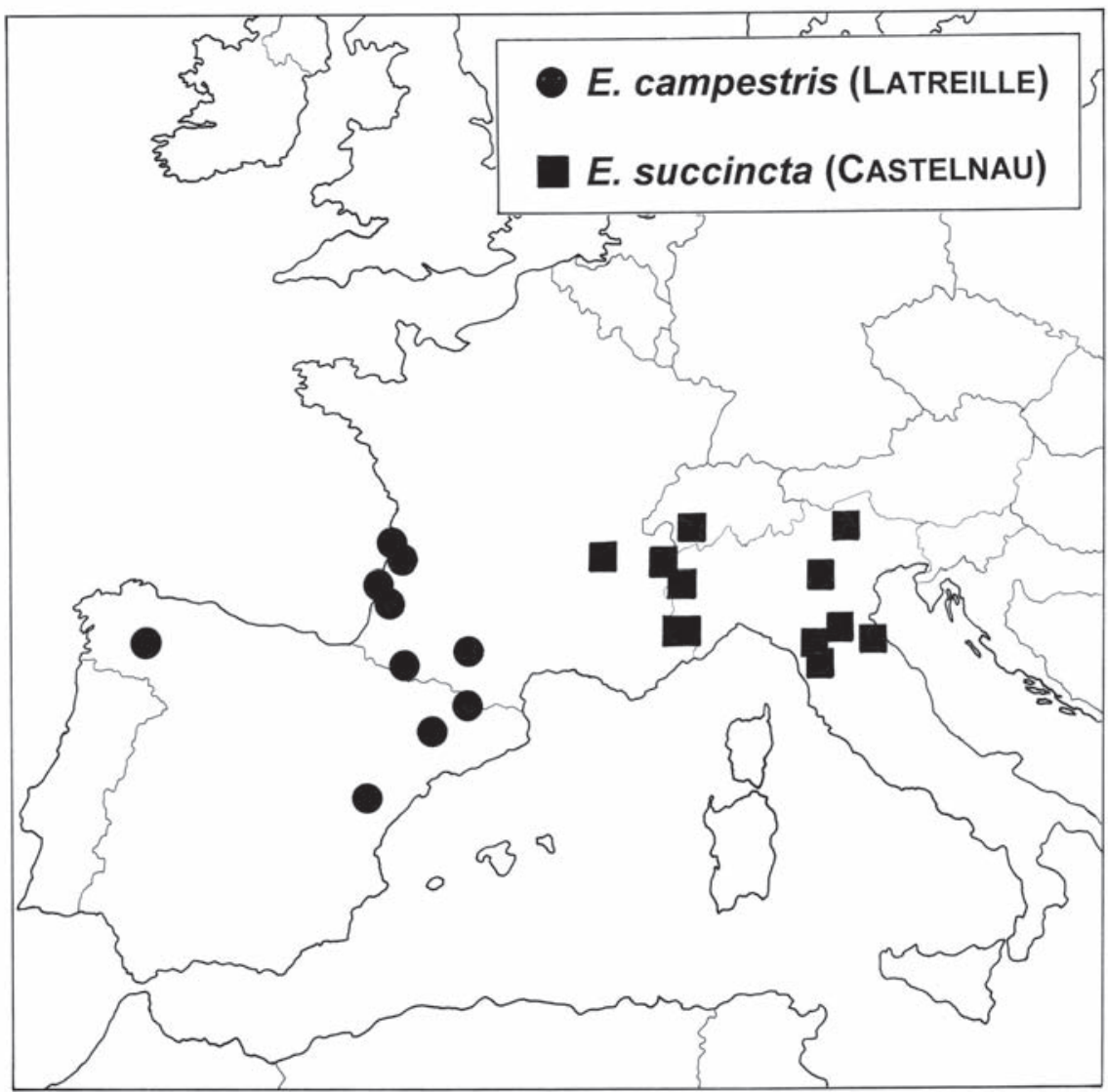

Fig. 35: Collecting localities of the examined material of Exomala campestris (circles) und Exomala succincta (squares).

\section{Description:}

Head, pronotum and scutellum black, shining, often with weak metallic lustre. Elytra yellowish brown, moderately shining; dark marks almost always well developed (figs 17-22); usually more or less broadly blackened along the periphery, on the umbone and on the area around the scutellum, and with a transversal black band.

Clypeus broadly rectangular; sides parallel; fore edge reflexed and weakly convex; anterior angles rounded; punctation transversely rugose; clypeus sparsely, forehead and vertex densely covered with erect, light-coloured setae; with very dense, rugose punctation.

Antennal club rather short, outer face of last antennomere distinctly convex.

Pronotum laterally with an obtuse, blunt angle (fig. 10); basal margin disappearing before the postero-lateral angles; base straight in front of scutellum (fig. 10); with dense transverse, somewhat rugose punctation and long, erect light-coloured setae.

Scutellum (fig. 10) broadly semicircular; densely punctate, setose.

Elytra (figs 17-22) broadest approximately in the middle; odd intervals feebly convex and weakly setose; all intervals with more or less dinstinct transverse, rugose punctation. 


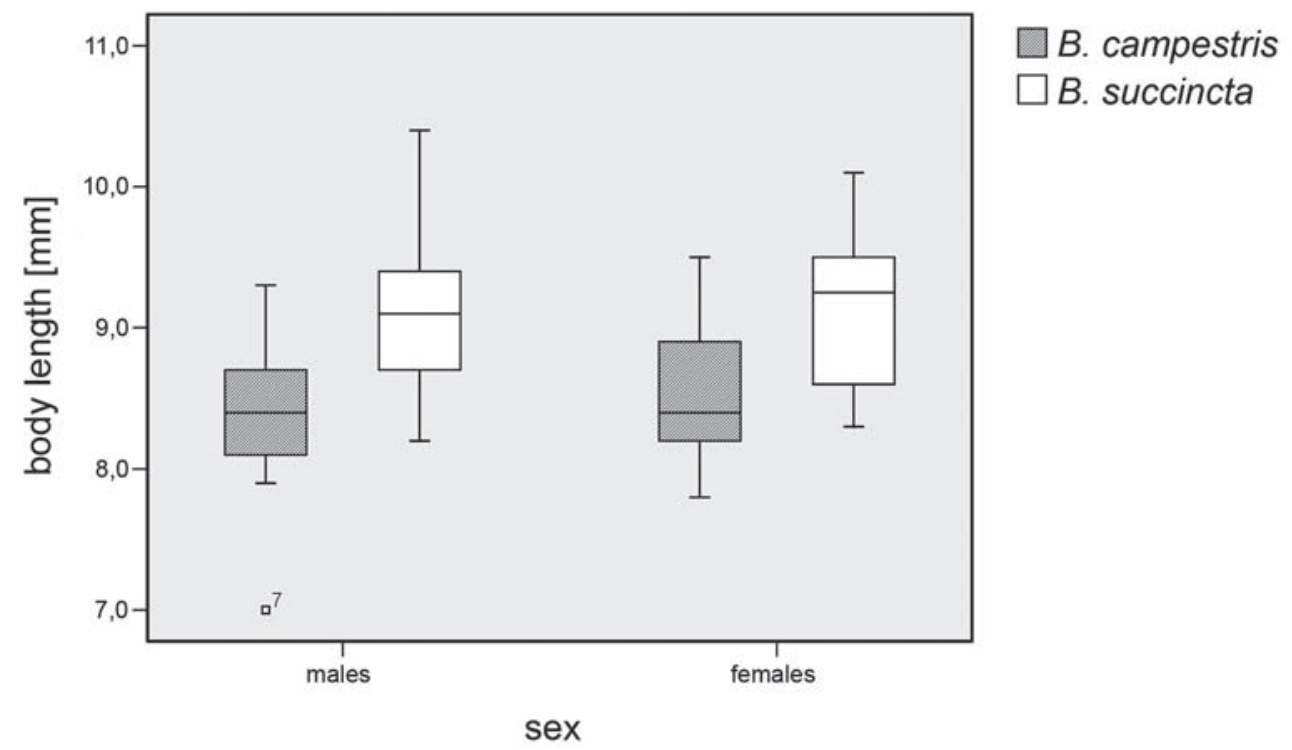

Fig. 36: Boxplots of the body length of males and females of E. campestris and E. succincta.

Pygidium densely transversely rugose; with moderately dense, long, light-coloured pilosity.

Ventral face and femora with rather long light-coloured setae.

Inner claw of fore tarsi in males (fig. 9) relatively long, approximately half as long as last tarsal joint.

\section{Distribution:}

In fig. 23 the locality data of the examined material are mapped. According to our data and recent literature, the distribution patterns of E. campestris and E. succincta can be described as follows.

The distribution area of Exomala campestris lies roughly in the triangle between the Pyrenees, the Cantabric mountains and the Iberian Central sierras (Sistema Central). In the south the species reaches Madrid and Guadalajara (BÁGuena 1967: 435, sub: Blitopertha campestris). In the north its distribution area includes the French Pyrenees and the lowlands of Landes and Médoc up to the Atlantic Ocean.

In general terms E. succincta is a species of the southern Alp valleys, distributed from Lyon in the west to Slovenia in the east. In Italy its distribution area does also include the northern Apennines (Emilia-Romagna, Toscana).

Therefore, according to the available data, E. campestris and E. succincta show an allopatric distribution, their respective geographic ranges are neither overlapping nor connected. They are separated by the Rhône valley, the Massif Central and the Cévennes in central France.

\section{Differential diagnosis:}

The differences on which the very similar species E. campestris and E. succincta can be separated are given in the table below. 
Tab. 1: Morphological differences between E. campestris and E. succincta.

\begin{tabular}{|c|c|c|}
\hline character & E. campestris & E. succincta \\
\hline $\begin{array}{l}\text { inner claw of } \\
\text { fore tarsi }\left(0^{+1}\right)\end{array}$ & $\begin{array}{l}\text { shorter than half the length of last } \\
\text { tarsal joint (fig. 4) }\end{array}$ & $\begin{array}{l}\text { as long as half the length of last tarsal joint } \\
\text { (fig. 9) }\end{array}$ \\
\hline body length & $\begin{array}{l}7.0-9.5 \mathrm{~mm}(\text { mean } 8.48 \mathrm{~mm}) \text { (fig. } 6 \text {, } \\
\text { table 2) }\end{array}$ & 8.2-10.4 mm (mean $9.13 \mathrm{~mm}$ ) (fig. 36, table 2) \\
\hline $\begin{array}{l}\text { antennal club } \\
\left(0^{*}\right)\end{array}$ & $\begin{array}{l}\text { elongate, outer face of last antenno- } \\
\text { mere weakly convex }\end{array}$ & $\begin{array}{l}\text { less elongate, outer face of last antennomere } \\
\text { distinctly convex }\end{array}$ \\
\hline pronotum & $\begin{array}{l}\text { sides evenly rounded (fig. 5); } \\
\text { basal margin reaching postero-lateral } \\
\text { angles, sometimes very faint there; } \\
\text { base in front of scutellum evenly } \\
\text { rounded, convex (fig. 5) }\end{array}$ & $\begin{array}{l}\text { sides with an obtuse, blunt angle (fig. 10); } \\
\text { basal margin disappearing before the postero- } \\
\text { lateral angles; base infront of scutellum straight } \\
\text { (fig. 10) }\end{array}$ \\
\hline scutellum & $\begin{array}{l}\text { mostly narrow and elongate, rarely } \\
\text { semicircular (fig. 5) }\end{array}$ & wide, semicircular (fig. 10) \\
\hline elytra & $\begin{array}{l}\text { dark marks usually reduced, } \\
\text { transversal band rarely } \\
\text { (figs 11-16) }\end{array}$ & $\begin{array}{l}\text { dark marks, including the transversal band, almost } \\
\text { always well developed (figs 17-22) [cf. RoBERT } \\
\text { (1992): fig. 2, sub: Blitopertha campestris LATR.] }\end{array}$ \\
\hline male genitalia & $\begin{array}{l}\text { sides of parameres straight in dorsal } \\
\text { view (fig. 1); } \\
\text { each paramere evenly narrow before } \\
\text { the apex, in ventral view (fig. 2); } \\
\text { ventral plate narrow and elongate } \\
\text { (fig. 2) }\end{array}$ & $\begin{array}{l}\text { sides of parameres sinuate in dorsal view (fig. 6); } \\
\text { each paramere broadened before the apex, in } \\
\text { ventral view (fig. } 7 \text { ); } \\
\text { ventral plate trapezoidal, very wide basally (fig. } 7 \text { ) }\end{array}$ \\
\hline
\end{tabular}

Tab. 2: Body length of males and females of E. campestris and E. succincta (minimum, maximum, mean, standard deviation, median). The differences in mean between E. campestris and E. succincta (males, females and overall) are highly significant (T-test, $\mathrm{p}<0,01)$.

\begin{tabular}{|l|l|l|l|l|l|l|}
\hline & $\operatorname{sex}(\mathbf{n})$ & $\min$ & $\max$ & mean & SD & median \\
\hline \multirow{4}{*}{ E. campestris } & males (13) & 7.0 & 9.3 & 8.35 & .555 & 8.40 \\
\cline { 2 - 7 } & females (29) & 7.8 & 9.5 & 8.54 & .455 & 8.40 \\
\cline { 2 - 7 } & overall (42) & 7.0 & 9.5 & 8.48 & .489 & 8.40 \\
\hline \multirow{4}{*}{ E. succincta } & males (45) & 8.2 & 10.4 & 9.09 & .505 & 9.10 \\
\cline { 2 - 7 } & females (34) & 8.3 & 10.1 & 9.18 & .524 & 9.25 \\
\cline { 2 - 7 } & overall (79) & 8.2 & 10.4 & 9.13 & .512 & 9.20 \\
\hline
\end{tabular}

\section{Key to the species of Neoblitopertha}

1 Sides of clypeus parallel; combined lengths of joints $1-4$ of fore tarsi in males as long as joint 5 or longer.

2

- $\quad$ Clypeus dilated; combined lengths of joints 1-4 of fore tarsi in males distinctly shorter than joint 5; male genitalia: figs 33, 34. (eastern Turkey) bileki Petrovitz, 1968

2 Pronotum glabrous on disc, only sides setose; widest a little before the base; basal margin reaching the postero-lateral angles; male genitalia: figs 31, 32. (Montenegro, Albania, Greece) adriatica Petrovitz, 1968 
- $\quad$ Pronotum entirely setose; widest approximately in the middle; basal margin indistinct or missing in the area of the postero-lateral angles. 3

3 Spur of protibia inserted opposite to excision between the two lateral teeth in males (Italy: Calabria, Sicily). leonii (Luigioni, 1932)

- $\quad$ Spur of protibia inserted opposite to basal lateral tooth in males. 4

4 Inner claw of fore tarsi in males less than half as long as last tarsal joint; sides of pronotum evenly rounded; scutellum most often narrow, rarely semicircular; dark marks of elytra often reduced; male genitalia: figs 1-3, 23-26. (northern Spain, Pyrenees, southwestern France) campestris (Latreille, 1804)

- $\quad$ Inner claw of fore tarsi in males as long as half the length of the last tarsal joint; sides of pronotum with an obtuse, blunt angle; scutellum broad, semicircular; dark marks of elytra almost always extensive; male genitalia: figs 6-8, 27-30. (Alps and northern Appenines: France, Switzerland, Austria, Italy, Slovenia) succincta (CASTELnaU, 1840)

\section{Acknowledgements}

For the kind support and loan of material we thank the collection managers of the following institutions: M. Baehr (ZSM), F. Geller-Grimm (NSMW), O. Jäger (SMTD), W. Schawaller (SMNS), M. Uhlig und J. FrISCH (MNHB), as well as all the private collectors mentioned in the material sections for providing their material for examination.

\section{Literature}

ÁDÁM, L. 2003: Faunisztikai adatok a Kárpát-medencéböl (Coleoptera: Scarabaeoidea). - Folia Historico Naturalia Musei Matraensis 27: 101-136.

Báguena, L. C. 1955: Escarabaeidae nuevos o muy interessantes de la fauna ibero-balear y pirenaica. - Eos, Revista Española de Entomologica 31: 275-295.

Báguena, L. C. 1967: Scarabaeoidea de la fauna Ibero-Balear y Pirenaica. - Instituto Espanol de Entomologia. Madrid: 576 pp.

Bahillo, de la Puebla \& López-Colón, J. I. 1998: Contibución al conocimiento de los Scarabaeoidea del Pais Vasco y areas limitrofes (Coleoptera, Phytophaga). 6a. Nota: Fam. Rutelidae. - Estudios del Museo de Ciencias Naturales de Alava 13: 167-179.

Baraud, J. 1977: Coléoptères Scarabaeoidea. Faune de l'Europe occidentale: Belgique, France, GrandeBretagne, Italie, Péninsule Ibérique. - Supplément à la Nouvelle Revue d'Entomologie VII (1): 352 pp.

Baraud, J. 1991: Nouvelle classification proposée pour les espèces du genre Blitopertha Reitter (1903) (Coleoptera Rutelidae). - Lambillionea 91: 46-62.

BARAUd, J. 1992: Coléoptères Scarabaeoidea d'Europe. Faune de France et régions limitrophes. 78. Fédération Française des Sociétés de Sciences Naturelles \& Société Linnéenne de Lyon, Lyon, ix + 856 pp., xi pls.

Bedel, L. 1911. Faune des Coléoptères du bassin de la Seine. IV $\left(1^{\mathrm{me}}\right)$ Scarabaeidae. - Paris: Publications de la Société Entomologique de France: 164 pp.

Benitez-Donoso, A. \& Garcia-Parrón, M. J. 1984: Los Scarabaeoidea (Coleoptera) de la coleccion del Departamento de Zoologia de la Universidad de Oviedo, II. - Familia Melolonthidae y Rutelidae. - Boletin de Ciencias de la Naturaleza I. D. E. A. 34: 91-104.

Carpaneto, G. M. \& Piattella, E. 1995: Coleoptera Polyphaga V (Lucanoidea, Scarabaeoidea). - In: Minelli, A.; Ruffo, S. \& La Posta, S. (eds.), Checklist delle specie della fauna italiana. Fascicolo 50 Bologna: Edizione Calderini: 18 pp.

Castelnau, F. L. De 1840: Histoire Naturelle des animaux articulés, annelides, crustacés, arachnides, myriapodes et insectes. Tome deuxième. Histoire Naturelle des Insectes Coléoptères. - Paris: P. Duménil: 564 pp, 38 pls. 
Erichson, W. F. 1847: Naturgeschichte der Insecten Deutschlands. Erste Abtheilung. Coleoptera. Dritter Band. Lieferung 4. - Berlin: Nicolaischen Buchhandlung: 481-640.

FABRICIUS, J. C. 1787: Mantissa Insectorum, sistens eorum Species nuper detectas, adjectis Characteribus genericis, Differentiis specificis, Emmendationibus, Observationibus. - Hafniae: C. G. Proft, Vol. 1: xx +348 pp.

Galante, E. 1984: Sobre los escarabeidos (Col., Scarabaeoidea) de la Peninsula Ibérica (II). - Boletin de la Asociación espańola de Entomologia 8: 5-12.

Gmelin, J. F. 1790: Caroli a Linné, Systema Naturae per Regna tria Naturae, secundum Classes, Ordines, Genera, Species, cum caracteribus, differentiis, synonymis, locis. Editio decima tertia, aucta, reformata. Tomus 1, Pars IV. - Lipsiae: G. E. Beer: 1517-2224.

Harold, E. v. 1869: Scarabaeidae. Pp. 979-1346. - In: Gemminger, M. \& E. von Harold (eds), Catalogus coleopterorum hucusque descriptorum synonymicus et systematicus. Tom. IV. Monachii: E. H. Gummi: 979-1346.

Herbst, J. F. W. 1783: Kritisches Verzeichniss meiner Insectensammlung. - Archiv der Insectengeschichte, 4: 1-72.

Horion, A. 1958: Faunistik der Mitteleuropäischen Käfer. VI: Lamellicornia (Scarabaeidae - Lucanidae). - Überlingen-Bodensee: A. Feyel: VIII-XXII, 1-287 pp.

International Commission on Zoological Nomenclature 1999: International code of zoological nomenclature, Code international de nomenclature zoologique. Fourth Edition. - London: International Trust for Zoological Nomenclature: xxix + $306 \mathrm{pp}$.

Horn, W.; Kahle, I.; Friese, G. \& Gaedike, R. 1990: Collectiones entomologicae. Ein Kompendium über den Verbleib entomologischer Sammlungen der Welt bis 1960. Teil I: A bis K, Teil II: L bis Z. - Berlin: Akademie der Landwirtschaftswissenschaften der Deutschen Demokratischen Republik: 573 pp. incl. 35 pl.

Jameson, M. L.; Micó, E. \& Galante, E. 2007: Evolution and phylogeny of the scarab subtribe Anisopliina (Coleoptera: Scarabaeidae: Rutelinae: Anomalini). - Systematic Entomology 32 (3): 429-449.

Klausnitzer, B. \& Krell, F.-T. 1996: Überfamilie: Scarabaeoidea. Pp. 11-89. - In: Klausnitzer, B.: Die Larven der Käfer Mitteleuropas, Vol. 3, Polyphaga, Teil 2, Krefeld: Goecke \& Evers; Jena, Stuttgart: Gustav Fischer Verlag: 335 pp.

Косн, K. 1991 (1989): Die Käfer Mitteleuropas. Ökologie. Bd. 2. - Krefeld: Goecke \& Evers: 382 pp.

Krell, F.-T. 1995: Die Lamellicornia (Coleoptera) der Käfersammlung Dr. Theodor Hüeber in den Naturkundlichen Sammlungen der Stadt Ulm, Bundesrepublik Deutschland. - Mitteilungen des Vereins für Naturwissenschaft und Mathematik Ulm/Donau 36/37 (1993-1995): 49-87.

LATreille, P. A. 1804: Histoire naturelle, génerale et particulière, des Crustacés et des Insectes. Ouvrage faisant suite aux oeuvres de Leclerc de Buffon, et partie du cours complet d'Histoire naturelle rédigé par C. S. Sonnini, membre de plusieurs sociétés savantes. Tome dixiéme. - Paris: F. Dufart: 445 pp., pls. 81-89.

Leplat, J. 1998: Blitopertha campestris hispanica (Col. Scarabaeidae) dans les Pyrenees-Orientales. - Rutilans 1 (2): 58, 60.

Luigioni P. 1932: Revisione dei Coleotteri della collezione Leoni. V. Una nuova specie del genere Phyllopertha Kirby (Blitopertha Reitt.) (Coleoptera - Fam. Scarabaeidae) dell'Italia meridionale. - Bollettino del Laboratorio di Entomologia del R. Istituto Superiore Agrario di Bologna 5: 138-142.

Lucht, W. H. 1987: Katalog. - In: Freude, H.; Harde, K. W. \& Lohse, G. A.: Die Käfer Mitteleuropas. - Krefeld: Goecke \& Evers: 342 pp.

Machatschke, J. W. 1969: Familienreihe Lamellicornia. Pp. 265-371. - In: Freude, H.; Harde, K. W. \& Lohse, G. A: Die Käfer Mitteleuropas, Vol. 8 (Teredilia, Heteromera, Lamellicornia). - Krefeld: Goecke \& Evers: 388 pp.

Micó, E. \& Galante, E. 2002: Atlas fotográfico de los escarabeidos floricolas ibero-baleares. - Argania editio, Barcelona: 80 pp.

MıкšIč, R. 1959: Dritter Nachtrag zur „Fauna Insectorum Balcanica-Scarabaeidae“. - Godisnjak Bioloskog Instituta u Sarajevo XII (1/2): 47-136. 
MıкšIČ, R. 1970: Katalog der Lamellicornia Jugoslawiens (Insecta - Coleoptera). - Institut za simarstvo - posebo izdanje, Sarajevo: $71 \mathrm{pp}$.

Mulsant, E. 1842: Histoire naturelle des Coléoptères de France. Lamellicornes. - Paris: Maison Libraire, Lyon: Imprimerie de Dumoulin, Ronet et Sibuet: viii + 626 pp., 3 pls.

Mulsant, E. \& Rey, C. 1871: Histoire Naturelle des Coléoptères de France. Lamellicornes - Pectinicornes. - Paris: Deyrolle: $735+42$ pp., 3 pls.

Ohaus, F. 1918: Scarabaeidae: Euchirinae, Phaenomerinae, Rutelinae. Pars 66, Vol. 20 (1). - In: S. Schenkling (ed.), Coleopterorum Catalogus. Berlin: W. Junk: 241 pp.

Olivier, G. A. 1789: Entomologie, ou Histoire Naturelle des Insectes, avec leurs caractères génériques et spécifiques, leur description, leur synonymie, et leur figure enluminée. Coléoptères. Tome premier. - Paris: Baudouin: $\mathrm{xx}+433$ pp. (eight chapters paginated separately).

Paulian, R. 1959: Faune de France, 63: Coléoptères Scarabéides (deuxième édition, revue et augmentée). - Paris: Lechevalier: 298 pp.

Paulian, R. \& Baraud, J. 1982: Faune des Coléoptères de France. II, Lucanoidea et Scarabaeoidea. Encyclopédie Entomologique, Paris: Editions Lechevalier 43: 477 pp., 16 pls.

Pesarini, C. 2004: Insetti della Fauna Italiana, Coleotteri Lamellicorni. - Natura vol. 93, Fasc. 2. Milano, Giugno, 132 pp.

Petrovitz, R. 1968: Ergebnisse zoologischer Sammelreisen in die Türkei. Lamellicornia, Coleoptera. Zweite Folge. - Annalen des Naturhistorischen Museums Wien 72: 465-491.

Petrovitz, R. 1969a: Ergebnisse der Albanien-Expedition 1961 des Deutschen Entomologischen Instituts. 77. Beitrag, Coleoptera: Scarabaeidae II (Glaphyridae, sericinae, Melolonthinae, Rutelinae, Hopliinae, Cetoniinae, nebst Nachträgen zu Trichiinae und Valginae). - Beiträge zur Entomologie 19 (7/8): 861-885.

Petrovitz, R. 1969b: Ergänzungen und Berichtigungen zu: Ad. Horion / Faunistik der mitteleuropäischen Käfer, VI/1858, Lamellicornia. II. Teil. - Zeitschrift der Arbeitsgemeinschaft österreichischer Entomologen, 21. Jhg. (4): 104-105.

Piatella, E. \& Sabatinelli, G. 1994: Osservazioni sul genere Exomala e note sulle specie della fauna italiana (Coleoptera, Scarabaeoidea, Rutelidae). - Fragmenta entomologica, Roma 26 (1): 151-163.

Reitter, E. 1903: Bestimmungs-Tabelle der Melolonthidae aus der europäischen Fauna und den angrenzenden Ländern. IV. Teil (Schluss): enthaltend die Rutelini, Hopliini, und Glaphyrini. LI. Heft (51). Sonderabdruck aus dem XLI Bande der Verhandlungen des Naturforschenden Vereiner in Brünn. Verlag von Edm. Reitter, Brünn: W. Burkart, 131 pp. (numbered 28-158).

Robert, J.-Y. 1992: Presence de Blitopertha campestris Latreille (Coleoptera Rutelidae) dans le departement du Jura. - Bulletin Mensuel de la Societe Linneenne de Lyon 61 (6): 175-179.

SchönherR, C. J. 1817:,Synonymia Insectorum, oder Versuch einer Synonymie aller bisher bekannten Insecten nach Fabricii Systema Eleutheratorum \&:c geordnet. Erster Band. Eleutherata oder Käfer. Dritter Theil: Hispa ... Molorchus. Skara: Lewerentzischen Buchdruckerey: xi + 506 pp., pls. 5, 6.

Zorn, C. 2006: Tribe Anomalini Mulsant, 1842. Pp. 251-276. - In: Löвl, I. \& Smetana, A. (eds.), Catalogue of Palaearctic Coleoptera. Volume 3: Scarabaeoidea - Scirtoidea - Dascilloidea - Buprestoidea - Byrrhoidea; Stenstrup: Apollo Books: 690 pp.

\section{Anschriften der Verfasser:}

ECKeHARD RöSSNER

Reutzstraße 5

19055 Schwerin

Deutschland

e-mail: roessner.e@t-online.de
Dr. Carsten Zorn

Suelzer Straße 52

17179 Gnoien

Deutschland

e-mail: czorn70@hotmail.com
Tristấo Branco

Rua de Camóes, $788,2^{\circ}$ Dto.

P-4000-142 Porto

Portugal

e-mail: tristao.branco@gmail.com 